\title{
İnvaziv Duktal Meme Kanserli Genç Olgularda MR Bulgularının, BRCA Mutasyon ve İmmünohistokimyasal Sonuçları ile Korelasyonu
}

\section{Correlation of MRI Findings with BRCA Mutation and Immunohistochemical Results in Young Patients with Invasive Ductal Breast Cancer}

\section{Kıyasettin Asil ${ }^{1}$, Furkan Ertürk Urfalı ${ }^{1}$, Mine Urfalı², Yasemin Anıl Eyüboğlu Tanrıverdi ${ }^{2}$, Havva Belma Koçer ${ }^{3}$}

${ }^{1}$ Sağlık Bakanlı̆̆ı Sakarya Üniversitesi Eğitim ve Araştırma Hastanesi, Radyoloji A.B.D., Sakarya, ${ }^{2}$ Sağlık Bakanlı̆̆̆ Sakarya Üniversitesi Eğitim ve Araştırma Hastanesi,Tibbi Genetik A.B.D., Sakarya,

${ }^{3}$ Sağlık Bakanlı̆̆ Sakarya Üniversitesi Eğitim ve Araştırma Hastanesi, Genel Cerrahi A.B.D., Sakarya,

Yazı̧ma Adresi / Correspondence:

Kiyasettin Asil

Sağlık Bakanlığı Sakarya Üniversitesi Eğitim ve Araştırma Hastanesi, Radyoloji A.B.D., Sakarya, 54100, Sakarya TÜRKiYE

T: +90 2642552466 E-mail: : drkiyasettin@gmail.com

Geliş Tarihi / Received : 02.05.2019 Kabul Tarihi / Accepted : 25.07.20199

Orcid :

Kiyasettin Asil https://orcid.org/0000-0001-9927-6282)

Furkan Ertürk Urfalı https://orcid.org/0000-0002-4875-7761)

Mine Urfalı https://orcid.org/0000-0029-2322-220)

Yasemin Anıl Eyüboğlu Tanrıverdi https://orcid.org/0000-0002-6869-4454)

Havva Belma Koçer https://orcid.org/0000-0002-9888-0661)

$\ddot{\mathrm{O} z}$

Amaç İnvaziv duktal karsinomalı 40 yaș altı hastalarda; immünohistokimyasal değerlendirme ve meme kanseri duyarlılık (BRCA) mutasyonları ile manyetik rezonans görüntülemede su ve yağın yankı asimetrisi ve en küçük kareler tahmini ile yinelemeli ayrışımı (IDEAL) ve Kartezyen sıralaması ile diferansiyel alt örnekleme (DISCO) sekanslarda elde edilen sinyal değerlerinin ilișkisini belirlemeyi amaçladık. ( Sakarya Tip Dergisi 2019, 9(3):406-411)

Gereç ve Çalışmamıza retrospektif olarak yaşları 30 ile 40 arasında değişen, patolojik olarak invaziv duktal meme kanseri tanısı alan 20 kadın hasta dahil edildi. Vakalarda Yöntemler immünohistokimyasal çalışmaların sonuçları araştırmaya dahil edildi. Ayrıca bu sonuçlara göre hastalar lüminal A, lüminal B, Her2 (+) ve triple negatif kanser (TNC) gruplarına ayrıldı. BRCA 1 ve 2 mutasyonu analizi yapıldı. Tedavi öncesi intravenöz Gadoliniumlu meme Manyetik rezonans görüntüleme (MRG) tetkiklerinde IDEAL ve DISCO sekanslarında lezyon, meme glandüler dokusu ve yağ dokusu değerleri ölçüldü. Veriler istatistiki olarak değerlendirildi.

Bulgular Çalışmaya alınan hastaların yaşları 30-40 arasında idi. Luminal A ve TNC grupları arasında MRG sinyal değerlerinde DISCO ve IDEAL sekansta lezyon/ yağ doku sinyali arasinda ve IDEAL sekansta lezyon sinyali/meme dokusu sinyali arasinda anlamlı fark mevcuttu. E kaderin ile IDEAL sekansta lezyon/meme dokusu sinyali arasinda korelasyon anlamlı idi (r: 0,446; p: 0,049).

Sonuç Luminal A ve TNC gruplarında farklılıklar olduğunu ve bu sayede bu iki grubun tanı sürecinde ayrlabilme ihtimali olduğu, lezyon boyutu ve lokal agresif davranışı gösteren E kaderin ile IDEAL sekansta sinyal değerinin ilişkili olduğunu bulduk.

Anahtar Manyetik rezonans görüntüleme; immünohistokimyasal tetkik; prognostik faktörler; meme kanseri; BRCA Kelimeler

\footnotetext{
Abstract

Objective The aim of this study was to determine the correlation between differential sub-sampling with cartesian ordering (DISCO) and Iterative decomposition of water and fat with echo asymmetry and least-squares estimation (IDEAL) values in magnetic resonance imaging with breast cancer susceptibility (BRCA) mutation analyses and immunohistochemical evaluation. ( Sakarya Med J 2019, 9(3):406-411).

Materials Twenty female patients between 30 and 40 years of age with pathologically diagnosed as invasive ductal breast cancer were included in our study. The values of immunohistochemical studies and Methods were included in the study and patients were classified as luminal A, luminal B, Her $2(+)$ and triple negative cancer(TNC). BRCA1 and 2 mutation analysis were performed. Lesions, breast glandular tissue and fat tissue values were measured in IDEAL and DISCO sequences of pre-treatment intravenous Gadolinium breast MRI examinations. The data were evaluated statistically.

Results The age of the patients included in the study was 30-40. There was a significant difference between the Luminal A and TNC groups in the MRI signal values between lesion / fat tissue signal in DISCO and IDEAL sequela and in lesion signal / breast tissue signal in IDEAL sequencing. Correlation between E-cadherin and IDEAL sequelae was significant.

Conclusion We found that there were differences in the Luminal A and TNC groups, and that there was a possibility that these two groups could be separated during the diagnostic process, and that the E-cadherin showing lesion size and local aggressive behavior was correlated with the signal value in the IDEAL sequence.

Keywords Magnetic resonance imaging; immunohistochemical examination; prognostic factors; breast cancer; BRCA
} 


\section{GIIRIŞ}

Meme kanseri 50 yaş altı kadınlarda kansere bağlı ölümlerin önemli bir nedeni olup tüm dünyada kanser teşhislerinin beşte birini oluşturur. ${ }^{1,2}$ Meme kanseri tanılı hastalarda magnetik rezonans görüntülemenin (MRG) asıl rolü lokal evreleme olup, yeni yayınlanmış çok merkezli bir çalışmada gösterilen neoadjuvan kemoterapinin erken etkinliğini öngörmede yardımcıdır. Lezyon boyutu ve aksiller lenf nodu varlığı MRG ile değerlendirilebilmekte olup tedavi öncesi prognoz belirlemede ve tedaviyi şekillendirmede önemlidir. ${ }^{3}$

İmmünohistokimyasal değerlendirmeler uzun zamandır prognostik belirteçler olarak kabul görmekte olup proliferasyon aktivitesi, mitoz oranı ve histolojik derece hakkında bilgi vermektedir. İmmünohistokimyasal değerlendirme sonucu yapılan lüminal A, lüminal B, İnsan deri reseptör faktör 2 (HER 2) (+) ve üçlü olumsuz kanser (TNC) sınıflandırmaları endokrin tedavi kararı ve kemoterapotik ajan seçiminde esastır., ${ }^{4}$

meme kanseri duyarlılık(BRCA)1 ve BRCA2 genleri 17q ve $13 \mathrm{q}$ kromozomunda bulunur ve hücre büyümesini önleyen faktörleri kodlar. Bu faktörler hücre döngüsü kontrolü, gen transkripsiyonu regülasyonu, Deoksiribo Nükleik Asit (DNA) hasar onarımı, apoptoz ve diğer önemli hücresel işlemlerde rol oynar. ${ }^{6}$ Taşıyıcı olmayanlarla karşılaştırıldığında, BRCA1 ile ilişkili meme kanserleri genellikle yüksek gradelidir. Bu tümörler genellikle üçlü negatiftir ve sitokeratin 5/6 (CK5 / 6), siklin E ve p53'ü eksprese eder. Çalışmamızda 40 yaş altı tedavi öncesi elde olunmuş dinamik kontrastlı meme MRG de sinyal değerleri ve lezyon özellikleri ile immünohistokimyasal değerlendirimi ve BRCA1-2 mutasyon analizi arasındaki ilişkiye bakmayı amaçladık.

\section{GEREÇ ve YÖNTEMLER}

Çalışmamızda retrospektif olarak 1 Ocak 2017 - 1 Aralık 2018 tarihleri arasinda hastanemizde kontrastlı meme MRG ve BRCA 1-2 mutasyon analizi yapılmış, immüno- histokimyasal analizleri bulunan meme kanserli hastalar dahil edilmiştir. Bu çalışma kesitsel tipte tanımlayıcı bir çalışmadır. İncelemeye alınan 20 kadın olgunun tedavi planlanmadan önce çekilen meme MRG incelemesi, östrojen ve progesteron reseptörler proteinleri, Ki67, C-erbB-2, E kaderin ve patolojik immunohistokimyasal sınıflamas1, genetik testlerine bakıldı. Hastaların kontrastlı meme MRG'ları cihaza ait olan Advanced Visualisation Volume Share 7 iş istasyonunda tekrar değerlendirilmiştir. Hastalar yaş değişkeninin etkesini azaltmak amacı ile 30-40 yaş arasında seçilmiş kadın hastalar olup patolojik sonuçları invaziv duktal karsinoma çıkan olgulardır. Bu yaş aralığının dışındaki olgular veya bu patolojik tanının dışında kalan tüm meme maligniteleri hastaları dışlanmıştır. Ayrıca tanı sırasında MRG çekilmeyen tedavi sürecinde çekilen olgular ile östrojen ve progestoren reseptörler proteinleri, Ki67, C-erbB-2, E kaderin parametrelerinden herhangi biri çalışılmayan veya genetik testi yapılmayan tüm hastalar da dışlanmıştır. İncelemede GE Signa Voyager 1.5 Tesla (Chicago, Illinois USA) MR cihazında elde edilen görüntülerde IDEAL (Iterative decomposition of water and fat with echo asymmetry and least-squares estimation ) ve kontrast enjeksiyonu sonrası elde olunan DISCO (Differential Sub-sampling with Cartesian Ordering) sekanslarında kitle lezyonunun sinyal değerleri ve ayrıca lezyona en yakın salim meme glandüler dokusundan, memede yağ dokudan elde edilen değerlerin lezyon sinyallerine oranları alındı. Ayrıca meme kitlesinin boyutu, kontur özellikleri ve tutulu aksiller lenfadenopati varlığı gibi diğer görüntüleme bulguları araştırmamıza dahil edildi.

Tüm ölçümler SPSS (Statistical Package for the Social Sciences) versiyon 17 programı ile istatistiki olarak değerlendirildi. MRG incelemesinde incelenen sekanslarda ölçülen sinyal değerleri ve bunların orantıları üzerinde normallik sınaması olarak Kolmogorov-Smirnov normallik testi ve Chi-square testleri ile yapılmıștır. Bu normallik sınamasına uyumlu olarak karşılaştırmalar one way ANOVA testi ve Kruskal-Wallis testi kullanılmıştır. İki grup arasındaki farklılıklar parametrik değerlerde student 
T testi ve nonparametrik değerlerde Mann-Whitney U testi ile bakılmıştır. Değerler arasında korelasyon Pearson Korelasyon testi ile bakılmıştır. Testlerde $\mathrm{p}<0,05$ değeri anlamlı kabul edilmiştir.

Araştırmamız için T.C. XXXXXX Üniversitesi' nden 71555473/050.01.04/93 sayı ile etik kurul onayı alınmıştır.

\section{BULGULAR}

Çalışmaya alınan hastaların yaşları 30-40 arasında (ortalama 36,20 \pm 3,76 standart sapma (SD)) idi. Hastalarda saptanan lezyonların ortalama çapı 30,12 \pm 15,49 mm ( \pm SD) olup lezyonların 15'inin konturları spiküle iken 4' ünde mikrolobule ve bir tanesinin düzenli idi. Hastaların 15 tanesinde aksiller bölgede lenf nodu tutulumu varken 5 tanesinde tutulum yoktu. Yapılan ölçümlerde lezyonlarin DISCO sekansta ortalama sinyalleri 2562,90 \pm 562,89 $( \pm \mathrm{SD})$ ve IDEAL sekansta ortalama sinyalleri 761,25 \pm 150,93 ( \pm SD) olarak ölçüldü. Bu sinyal değerleri aynı memenin en yakın normal meme dokusu ve yağ lobulu sinyalleri ile orantılandı (Tablo 1).

\begin{tabular}{|l|c|c|c|c|}
\hline \multicolumn{4}{|l|}{$\begin{array}{l}\text { Tablo 1: Yaş, lezyonun en geniş çapı ve MRG' de DISCO ve IDEAL se- } \\
\text { kanslarda sinyal değerlerinin dağılım tablosu (IDEAL: Su ve yağın yankı } \\
\text { asimetrisi ve en küçük kareler tahmini ile yinelemeli ayrışımıDISCO: } \\
\text { Kartezyen sıralaması ile diferansiyel alt örnekleme () }\end{array}$} \\
\hline $\begin{array}{l}\text { Parametreler } \\
\text { En az }\end{array}$ & En çok & Ortalama & $\begin{array}{c}\text { Standart } \\
\text { sapma }\end{array}$ \\
\hline Yaş(Yıl) & 30,00 & 40,00 & 36,20 & 3,76 \\
\hline $\begin{array}{l}\text { Çap(mm) } \\
\text { DISCO sekansta } \\
\text { lezyon sinyali }\end{array}$ & 9,50 & 62,50 & 30,12 & 15,48 \\
\hline $\begin{array}{l}\text { IDEAL sekansta } \\
\text { lezyon sinyali }\end{array}$ & 4915 & 3928 & 2562,90 & 562,89 \\
\hline $\begin{array}{l}\text { DISCO sekansta } \\
\text { lezyon/meme dokusu } \\
\text { sinyali }\end{array}$ & 1,305 & 5,22 & 2,03 & 0,80 \\
\hline $\begin{array}{l}\text { DISCO sekansta } \\
\text { lezyon/yağ dokusu } \\
\text { sinyali }\end{array}$ & 9,505 & 34,27 & 18,27 & 6,18 \\
\hline $\begin{array}{l}\text { IDEAL sekansta } \\
\text { lezyon/meme dokusu } \\
\text { sinyali }\end{array}$ & 1,081 & 2,388 & 1,53456 & 0,343849 \\
\hline $\begin{array}{l}\text { IDEAL sekansta } \\
\text { lezyon/yağ dokusu } \\
\text { sinyali }\end{array}$ & 2,197 & 5,556 & 3,96352 & 1,051142 \\
\hline $\begin{array}{l}\text { IDEAL: Su ve yağın yankı asimetrisi ve en küçük kareler tahmini ile } \\
\text { yinelemeli ayrışımı } \\
\text { DISCO: Kartezyen sıralaması ile diferansiyel alt örnekleme }\end{array}$ & \\
\hline
\end{tabular}

Hastaların sadece bir tanesinde BRCA 1 pozitifti ve BRCA 2 gen mutasyonu tüm hastalarda negatifti. E kaderin hastaların 13 tanesinde pozitifti ve 7 tanesinde negatifti. Östrojen reseptörü proteini hastaların 3 tanesinde kuvvetli pozitif, 11 tanesinde pozitif ve 6 tanesinde negatifti. Progesteron reseptörü proteini hastaların 1 tanesinde kuvvetli pozitif, 10 tanesinde pozitif ve 9 tanesinde negatifti. C-erbB-2 skorları üç hastada 3, üç hastada 2, bir hastada 1 ve on üç hastada 0 idi. Ki67 hastalarda ortalama $18,74 \pm 15,42( \pm S D)$ idi. Immünohistokimyasal sınıflamalarına göre hastaların 10 tanesi luminal A, 5 tanesi luminal B, 4 tanesi TNC meme kanseri ve bir her2/neu grubundandi.

İmmunohistokimyasal sınıflamaya göre yapılan MRG incelemesinde IDEAL ve DISCO sekanslarda yapılan tüm sinyal değerleri ölçümleri ve orantıları arasında anlamlı farklılık saptamadık ( $\mathrm{p}>0,05$ Kruskal-Wallis testi Tablo 2). MRG de DISCO sekansta lezyon siyali ile meme dokusu sinyal oranında da immunohistokimyasal sinıflamaya göre anlamlı fark yoktu (p:0,823 ANOVA test).

Luminal A ve TNC grupları arasında MRG sinyal değerlerinde DISCO ve IDEAL sekansta lezyon/ yağ lobulü sinyali arasinda ve IDEAL sekansta lezyon sinyali/meme dokusu sinyali arasında anlamlı fark mevcuttu (sirasıyla p: 0,48, p: 0,24, p: 0,24 Mann-Whitney U test). Luminal A ve luminal B ile luminal B ve TNC grupları arasında MRG incelemesinde sinyal değerleri arasında anlamlı fark yoktu.

Lezyon boyutu ile lezyonun MRG sekanslarındaki sinyalleri arasında yapılan değerlendirmede IDEAL sekansta lezyon sinyali ile boyutu arasinda korelasyon mevcuttu (Pearson korelasyon testi, r:0,554 p: 0,011). Diğer değerlendirilen DISCO sekansta lezyon sinyali ve bu sinyallerin meme dokusu ve yağlı dokuya olan oranları ile lezyon boyutu arasında korelasyon yoktu ( $p>0,05)$. Ki67 değeri, C-erbB-2, östrojen ve progesteron reseptör protein seviyeleri ile MRG' de IDEAL ve DISCO sekansta lezyon sinyalleri ve bu sinyallerin oranı arasında korelasyon saptanma- 
$d_{1}(p>0,05)$. E kaderin ile IDEAL sekansta lezyon/meme dokusu sinyali arasında korelasyon anlamlı idi (r: 0,446; p: 0,049 Pearson korelasyon testi).

\begin{tabular}{|c|c|c|c|}
\hline \multicolumn{4}{|c|}{$\begin{array}{l}\text { Tablo 2: Immünohistokimyasal subtiplere göre MRG de DISCO ve } \\
\text { IDEAL sekansların sinyal değerlerinin karşılaştırılması ( } p<0,05 \text { anlamlı, } \\
\text { Kruskal Wallis Testi) }\end{array}$} \\
\hline Parametreler & Ki kare & p değeri & $\begin{array}{c}\text { Ortalama } \pm \\
\text { Standart sapma }\end{array}$ \\
\hline $\begin{array}{l}\text { DISCO sekansta } \\
\text { lezyon sinyali }\end{array}$ & 3,996 & 0,262 & $\begin{array}{l}\text { 1) } 2555,30 \pm 400,43 \\
\text { 2) } 2911,80 \pm 655,69 \\
\text { 3) } 2105 \pm 678,92\end{array}$ \\
\hline $\begin{array}{l}\text { DISCO sekansta } \\
\text { meme dokusu sinyali }\end{array}$ & 1,913 & 0,591 & $\begin{array}{l}\text { 1) } 1290,20 \pm 327,47 \\
\text { 2) } 1493,60 \pm 276,11 \\
\text { 3) } 1220,25 \pm 268,41\end{array}$ \\
\hline $\begin{array}{l}\text { DISCO sekansta yağ } \\
\text { dokusu sinyali }\end{array}$ & 2,141 & 0,544 & $\begin{array}{l}\text { 1) } 142,80 \pm 40,78 \\
\text { 2) } 155,20 \pm 44,63 \\
\text { 3) } 177,75 \pm 71,20\end{array}$ \\
\hline $\begin{array}{l}\text { IDEAL sekansta } \\
\text { lezyon sinyali }\end{array}$ & 3,780 & 0,286 & $\begin{array}{l}\text { 1) } 700,40 \pm 145,48 \\
\text { 2) } 826,40 \pm 107,98 \\
\text { 3) } 848,25 \pm 185,28\end{array}$ \\
\hline $\begin{array}{l}\text { IDEAL sekansta meme } \\
\text { dokusu sinyali }\end{array}$ & 1,609 & 0,657 & $\begin{array}{l}\text { 1) } 527,70 \pm 107,02 \\
\text { 2) } 527,20 \pm 89,86 \\
\text { 3) } 478,50 \pm 204,66\end{array}$ \\
\hline $\begin{array}{l}\text { IDEAL sekansta yağ } \\
\text { dokusu sinyali }\end{array}$ & 1,208 & 0,751 & $\begin{array}{l}\text { 1) } 207,40 \pm 27,30 \\
\text { 2) } 202,60 \pm 60,39 \\
\text { 3) } 179,50 \pm 48,95\end{array}$ \\
\hline $\begin{array}{l}\text { DISCO sekansta } \\
\text { lezyon/meme dokusu } \\
\text { sinyali }\end{array}$ & 1,149 & 0,765 & $\begin{array}{l}1) 2,19 \pm 1,09 \\
\text { 2) } 1,98 \pm 0,34 \\
\text { 3) } 1,71 \pm 0,33\end{array}$ \\
\hline $\begin{array}{l}\text { DISCO sekansta } \\
\text { lezyon/yağ dokusu } \\
\text { sinyali }\end{array}$ & 6,274 & 0,990 & $\begin{array}{l}\text { 1) } 19,12 \pm 6,41 \\
\text { 2) } 19,71 \pm 5,41 \\
\text { 3) } 12,34 \pm 2,37\end{array}$ \\
\hline $\begin{array}{l}\text { IDEAL sekansta } \\
\text { lezyon/yağ dokusu } \\
\text { sinyali }\end{array}$ & 5,417 & 0,144 & $\begin{array}{l}1) 3,45 \pm 0,96 \\
\text { 2) } 4,35 \pm 1,17 \\
\text { 3) } 4,82 \pm 0,58\end{array}$ \\
\hline \multicolumn{4}{|c|}{$\begin{array}{l}\text { IDEAL: Su ve yağın yankı asimetrisi ve en küçük kareler tahmini ile } \\
\text { yinelemeli ayrışımı } \\
\text { DISCO: Kartezyen sıralaması ile diferansiyel alt örnekleme } \\
\text { İmmunohistokimyasal gruplamaya göre 1) Luminal A meme kanseri ; 2) } \\
\text { Luminal B meme kanseri; 3) TNC meme kanseri }\end{array}$} \\
\hline
\end{tabular}

TARTIŞMA

Meme kanseri kadınlar arasında en sık görülen ve görülme sıklığı giderek artan kanser tipidir. Rutin taramanın yaygınlaştırılması ve görüntüleme sistemlerindeki gelişmeler sayesinde erken evrede tanı alan vaka sayısı artış göstermektedir. ${ }^{8}$ Erken evrede tanı alan hasta sayısındaki artış ile hasta sağkalımı uzamış olup en uygun tedavi seçimi ve takipte kemoterapiye yanıt değerlendirimi için prognostik faktörler daha da önem kazanmaktadır. MRG’ nin meme görüntülemede ki önemi kullanıma girdiği günden, günümüze hızla artmış olup meme kanserinin lokal evrelemesinde tümör boyutunun daha iyi değerlendirilmesi, multifokal veya multisenterik kanserin değerlendirilmesi, kontralateral lezyonun ortaya konmasinda primer radyolojik tetkik olmuştur. ${ }^{9}$

Chang ve ark.'nın yaptığı çalışmada spiküle tümör konturunun düşük histolojik grade (I-II) ve pozitif progestoron reseptörü (PR) ile, rim tipi kontrastlanmanın yüksek histolojik grade, aksiller lenf nodu metastazı, büyük tümör boyutu ve Ki-67 indeksinde artış, erken pik kontrastlanmanın negatif östrojen reseptör ekspresyonu ile anlamlı korelasyon gösterdiği bildirilmiştir. ${ }^{10}$ Bizim yaptığımız çalışmada tümör boyutu ile MRG incelemesinde Ideal sekansta lezyondan alınan sinyaller arasinda korelasyon mevcuttu. Ancak Ki67 ile MRG' de IDEAL ve DISCO sekanslardan elde ettiğimiz ölçümler arasında korelasyon saptayamadık. Aldığımız örnek hasta grubu bu çalışmaya göre daha homejen olmakla birlikte sayısal olarak örnek hasta grubundaki immünohistıkimyasal gruplamalarda eşit dağılımın çıkmamış olması Ki67 ile MRG’ deki sinyal değerleri arasındaki korelasyonu etkiliyor olabilir. Ayrıca bu bulgumuzun MRG’ de lezyon boyutu arttıkça duyarlılığın artmasıyla uyumlu olabileceğini düşündük.

TNC meme kanserinde; belirgin sınır, düzgün kontur, T2 ağırlıklı görüntülerde hiperintensite ve rim şeklinde kontrastlanma gibi spesifik MR bulguları tanımlanmıştır. MRG' yi okuma kriterlerinin kanserlerin bu özelliğine göre uyarlanması MRG'nin neoadjuvan kemoterapiye yanıtı değerlendirmedeki etkisinin tedavi edilen kanserin moleküler sınıfına bağlı olması ve TNC' nin BRCA1 mutasyonu ile sık görülen birlikteliği nedeniyle önemlidir. ${ }^{11}$ Bizim çalışmamızda tek hastada BRCA1 gen mutastonu tespit edilmişti. Lezyon literatürle uyumlu olarak TNC grubundand 1 ve çalışmamızdaki tek düzgün kenarlı lezyondu. Biz çalışmamızdaki tek hastaya dayanarak böyle bir birliktelikden söz edemeyiz bu nedenle bu konuda geniş hasta gruplar1nı içeren çalışmalara halen ihtiyaç mevcuttur. Literatürde prognostik faktörler ile MRG de sinyal değerleri arasında 
korelasyonun bakıldığı sınırlı sayıda çalışma vardır.

Hormon reseptörü negatif meme kanseri, hormon reseptörü pozitif lüminal tip meme kanserine kıyasla 5 yıllık nüks oranı daha yüksektir. ${ }^{12}$ Ancak uzun dönemde östrojen reseptör proteini (ER)/PR varlığının prognostik etkisi belirsizdir.13 Aksiller nod negatif meme kanseri ile ilgili yapılan birçok çalışmada ER reseptör negatif, HER2 ve TNC alt tipleri kötü prognoz ile ilişkili bulunmuştur. ${ }^{12}$ Luminal A ve TNC grupları arasında MRG sinyal değerlerinde DISCO ve IDEAL sekansta lezyon/ yağ lobulü sinyali arasinda ve IDEAL sekansta lezyon sinyali/meme dokusu sinyali arasinda anlamlı fark mevcuttu (sirasıyla p:0,48, p:0,24, p: 0,24 Mann-Whitney U test). Luminal A ve luminal B ile luminal B ve TNC grupları arasında MRG incelemesinde sinyal değerleri arasında anlamlı fark yoktu. MRG incelemesinde luminal A ve TNC grupları arasındaki bu fark MRG' nin prognostik değerinin olabileceğini göstermektedir.

Östrojen veya progesteron reseptörlerinin varlı̆̆ adjuvan tamoksifen'den faydalanım açısından güçlü prediktif faktördür. Luminal A immünohistolojik tip meme kanseri MRG' de sıklıkla irregüler veya spiküler konturlu olması, heterojen kontrastlanması, periferik halo olmaması, peri-tümör ödem ve T2 ağılıklı görüntüde belirgin hiperintens olmaması ile tanımlanmaktadır. ${ }^{11}$ Luminal A ve B tümörlerinin MRG görünümlerini ayıran yayınlanmış bir bilgiye rastlamadık .Çalışmamızda da lüminal A ve B tipi immünohistokimyasal tip meme kanserlerinin MRG' de IDEAL, DISCO sekanslarındaki sinyal değerleri arasında anlamlı farklılık yoktu (p;0,462 ve p:0,086 Mann-WhitneyU testi).

C-erbB-2 proto-onkojeni, meme kanserli hastların yaklaşık\% 30 oranında fazla eksprese edilir. ${ }^{13}$ C-erbB-2 aşırı ekspresyonu agresif tümör ile ilişkilidir. Aksiller nod negatif hastaları içeren geniş kapsamlı bir çalışma, C-erbB-2' nin aşırı ekspresyonunun nüks için zayıf prognostik faktör olduğunu göstermiştir. Nod negatif, tümör boyutu $1 \mathrm{~cm}$ den küçük hastalar üzerinde yapılan çalışmalarda, HER2 ve TNC alt tipleri Lüminal A tipine kıyasla daha kısa nükssüz sağkalım ile ilişkili bulunmuştur. ${ }^{12} \mathrm{E}$ kaderinin ise klasik bir tümör baskılayıcı bir gen olduğu ve hücre mobilitesini azalttığ ${ }_{1}$ bildirilmiştir. E kaderin azalan tümörlerde lokal invazyonun da arttığı bildirilmiştir. ${ }^{14}$ Çalışmamızda C-erbB-2 skorları üç hastada 3, üç hastada 2, bir hastada 1 ve on üç hastada 0 idi ve C-erbB-2 ile IDEAL ve DISCO sekanslarında lezyon sinyalleri arasında anlamlı ilişki bulunmadı (sırasiyla p:0,901 ve p:0,157 Pearson testi). Ancak E kaderin ile IDEAL sekansta lezyon/meme dokusu sinyali arasında korelasyon anlamlı idi (r: 0,446; p: 0,049 Pearson korelasyon testi). Bu da bize lokal agresif tümörlerde IDEAL sekansının daha duyarlı olduğunu ve bu tür tümörlerin MRG ile daha erken ayırt edilebileceğini düşündürmüştür. Ancak bu konuda literatürde saptayabildiğimiz çalışmaya rastlamadik.

Sonuç olarak çalışmamızda invaziv duktal meme kanserli 40 yaş altı kadınlarda MRG' de sinyal değerlerinin Luminal A ve TNC gruplarında farklılıklar olduğunu ve bu sayede bu iki grubun tanı sürecinde ayrılabilme ihtimali olduğu, lezyon boyutu ve lokal agresif davranışı gösteren E kaderin ile IDEAL sekansta sinyal değerinin ilişkili olduğunu bulduk. Biz immünohistopatolojik sınıflamadaki kanser subtipleri hakkında önceden MRG ile fikir sahibi olunabileceğini ve geniş olgu gruplarıyla çalışıldığında MRG’ nin hasta prognozunu öngörebileceğini düşünüyoruz. 
Sakarya Tip Dergisi 2019;9(3):406-411

ASİL ve Ark., Meme Kanserinde Prognostik Faktörlerin MRG Ile Karşılatırılması

\section{Kaynaklar}

1. Shao G, Fan L, Zhang J, Dai G, Xie T. Association of DW/DCE-MRI Features with Prognostic Factors in Breast Cancer. The International Journal of Biological Markers 2017; 32(1):e118-e125.

2. Bray F, McCarron P, Parkin DM. The changing global patterns of female breast cancer incidence and mortality. Breast Cancer Research 2004; 6(6):229-239.

3. Hylton NM, Blume JD, Bernreuter WK, Pisano ED, Rosen MA, Morris EA, et al. Locally advanced breast cancer: MRI imaging for prediction of response to neoadjuvant chemother-apy - results from ACRIN 6657/I-SPY TRIAL. Radiology 2012; 263(3):663-672.

4. Modified from Schnitt SJ. Will molecular classification replace traditional breast pathology? Int J Surg Pathol 2010; 18:162S-166S.

5. Correa Geyer F, Reis-Filho JS. Microarray-based gene expression profiling as a clinical tool for breast cancer management: are we there yet? Int J Surg Pathol 2009; 17:285-302.

6. Wang F, Fang Q, Ge Z, Yu N, Xu S, Fan X. Common BRCA1 and BRCA2 mutations in breast cancer families: a meta-analysis from systematic review. Molecular biology reports 2012; 39:2109-2118.

7. Bordeleau L, Panchal S, Goodwin P. Prognosis of BRCA-associated breast cancer: a summary of evidence. Breast cancer research and treatment 2010; 119:13-24.

8. Bleyer A, Welch G. Effect of Three Decades of Screening Mammography on Breast-Cancer Incidence. N Engl J Med 2012; 367:1998-2005.
9. Kuhl CK. Current status of breast MRI imaging. Part 2. Clinical applications. Radiology 2007; 244(3):672-691.

10. Chang YW, Kwon KH, Choi DL, Lee DW, Lee HK, Yang SB, Kim Y, Seo DY. Magnetic Resonance Imaging of Breast Cancer and Correlation with Prognostic Factors. Acta Radiologica 2009; 50(9):990-998.

11. Alili C, Pages E, Curros Doyon F, Perrochia H, Millet I, Taourel P. Correlation between MR imaging - prognosis factors and molecular classification of breast cancers. Diagnostic and Interventional Imaging 2014; 95:235-242.

12. Kim H, Cho J, Kwon SY, Kang SH. Biologic subtype is a more important prognostic factor than nodal involvement in patients with stages I and II breast carcinoma. Ann Surg Treat Res 2016; 90(1):1-9

13. Reddy SM, Barcenas CH, Sinha AK, Hsu L, Moulder SL, Tripathy D, Hortobagyi GN, Valero $V$. Long-term survival outcomes of triple-receptor negative breast cancer survivors who are disease free at 5 years and relationship with low hormone receptor positivity. British Journal of Cancer 2018; 118:17-23.

14. Turan N, Ergen A, Arikan S, Yaylm I, Isbir T. The Role Of Mmp-3 And E-cadherin Polymorphisms In Breast Tumours. Deneysel Tip Araștırma Enstitüsü Dergisi 2012; 2(4):30-37. 